\title{
Cytotoxicity and physicochemical characterization of iron-manganese- doped sulfated zirconia nanoparticles [Corrigendum]
}

Al-Fahdawi MQ, Rasedee A, Al-Qubaisi MS, et al. Int J Nanomedicine. 2015;10:5739-5750.

On page 5739, Affiliation section, the affiliations " ${ }^{\text {"Institute }}$ of Bioscience, ${ }^{2}$ Department of Veterinary Pathology and Microbiology, Faculty of Veterinary Medicine, ${ }^{3}$ Catalysis Science and Technology Research Centre, Faculty of Science, ${ }^{4}$ Department of Chemistry, Faculty of Science, ${ }^{5}$ Biomedical Research Center, Qatar University, Doha, Qatar; ${ }^{6}$ Department of Cell and Molecular Biology, Faculty of Biotechnology and Biomolecular Sciences, Universiti Putra Malaysia (UPM), Serdang, Selangor, Malaysia; ${ }^{7}$ Department of Chemical Engineering, Northeastern University, Boston, MA, USA; ${ }^{8}$ Center of Excellence for Advanced Materials
Research, King Abdulaziz University, Jeddah, Saudi Arabia” should have read "I Institute of Bioscience, ${ }^{2}$ Department of Veterinary Pathology and Microbiology, Faculty of Veterinary Medicine, ${ }^{3}$ Catalysis Science and Technology Research Centre, Faculty of Science, ${ }^{4}$ Department of Chemistry, Faculty of Science, Universiti Putra Malaysia (UPM), Serdang, Selangor, Malaysia; ${ }^{5}$ Biomedical Research Center, Qatar University, Doha, Qatar; ${ }^{6}$ Department of Cell and Molecular Biology, Faculty of Biotechnology and Biomolecular Sciences, Universiti Putra Malaysia (UPM), Serdang, Selangor, Malaysia; ${ }^{7}$ Department of Chemical Engineering, Northeastern University, Boston, MA, USA; ${ }^{8}$ Center of Excellence for Advanced Materials Research, King Abdulaziz University, Jeddah, Saudi Arabia
International Journal of Nanomedicine

\section{Publish your work in this journal}

The International Journal of Nanomedicine is an international, peerreviewed journal focusing on the application of nanotechnology in diagnostics, therapeutics, and drug delivery systems throughou the biomedical field. This journal is indexed on PubMed Central, MedLine, CAS, SciSearch ${ }^{\circledR}$, Current Contents $\mathbb{R} /$ Clinical Medicine,

\section{Dovepress}

Journal Citation Reports/Science Edition, EMBase, Scopus and the Elsevier Bibliographic databases. The manuscript management system is completely online and includes a very quick and fair peer-review system, which is all easy to use. Visit http://www.dovepress.com/ testimonials.php to read real quotes from published authors. 